\title{
An Overview of Muslim Spiritual Parenting
}

\author{
Benaouda Bensaid (D)
}

check for

updates

Citation: Bensaid, Benaouda. 2021. An Overview of Muslim Spiritual Parenting. Religions 12: 1057. https://doi.org/10.3390/rel12121057

Academic Editors: Richard Woolley and Ellie Hill

Received: 12 October 2021

Accepted: 24 November 2021

Published: 29 November 2021

Publisher's Note: MDPI stays neutral with regard to jurisdictional claims in published maps and institutional affiliations.

Copyright: (C) 2021 by the author. Licensee MDPI, Basel, Switzerland. This article is an open access article distributed under the terms and conditions of the Creative Commons Attribution (CC BY) license (https:/ / creativecommons.org/licenses/by/ $4.0 /)$.
Faculty of Islamic Sciences, Istanbul Sabahattin Zaim University, Istanbul 34303, Turkey; benaouda.bensaid@izu.edu.tr

\begin{abstract}
Muslim life on the individual, family, and community levels continues to revolve around fundamental spiritual principles, themes, and values with corresponding meanings that impact purpose of life and even lifestyle. Muslim parents pursue ways and means to nurture their children's spirituality, strengthen their moral resilience, and shape their identity as effective members of society. This theoretical study explores Islamic insights into spiritual parenting, addressing questions around what defines spiritual parenting and constitutes its core tenets, characteristics and approaches, and principles and guidelines used by Muslims to raise spiritual children. This study identifies a rich Islamic conceptualization and theoretical approach to holistic spiritual parenting that engages with modernity and allows room for adaptation, creativity, and intercultural experience. Further empirical research is needed to shed light on the current dynamics of Muslim spiritual parenting, parents' struggles, accommodations, adaptations, as well as caregiver resistance in practices of spiritual parenting, which would help us better understand the needs and challenges facing Muslim families today and further enrich our understanding of comparative and cross-cultural parenting in multicultural societies.
\end{abstract}

Keywords: Islamic spiritual parenting; Muslim children; spirituality; Islamic education

\section{Introduction}

The study of spirituality continues to draw increased academic interest, especially with regards to its potential effects on shaping the meaning of life, driving motivation, contributing to development, and strengthening community bonds and religious networks. Despite ongoing debates surrounding the definition, position, and role of spirituality in society, many researchers today appreciate its crucial relevance to diverse areas of knowledge. For Muslim communities, spirituality represents a core component of religiosity, with far-reaching implications not only for religious identity formation and preservation, but also for interaction with other religious and spiritual traditions, cultures, and education, in addition to its crucial role in leadership development. Muslims today are increasingly preoccupied with transmitting their living spiritual traditions to future generations to ensure continuity in intra-generational and intergenerational traditions and spirituality. Themes of children's spirituality are as old as the Islamic spiritual tradition itself, and are interspersed throughout early Muslim literature on spirituality, mannerisms ( $a d a b)$, ethics, mysticism, and religious education in general. This falls within the general purview of Islamic learning and education, which embraces core issues such as parental religious responsibility and the rationale for the spiritual upbringing of children, in addition to concepts, approaches, and strategies set for children's spiritual care. Understanding the concept and dynamics of spiritual parenting helps understand the core values imbued in Muslim thought and collective consciousness, their profound persuasions, longings, and ambitions, and pathways that result in the intersection of modern education, training, and development situated within overlapping Muslims' circles of experience and inherent satisfaction.

The study of Muslim children's spirituality, and, by extension, Muslim spiritual parenting, is timely-especially with regards to its critical relevance to child development 
and behavioral theories, theories of learning, and global education, which seeks to create globally inclusive environments for students, thereby promoting a more nuanced understanding of multiple perspectives, and creating meaningful learning opportunities that explore cross-cultural perspectives (Pike 1997, p. 11). Spirituality helps articulate meanings of positive citizenship and the reciprocal and existential relationship between individual citizens and civil society. When society nurtures each citizen's pursuit of their highest purpose and calling in the interest of the greater good, they will then be able to experience true liberation and freedom (Rifkin 2016, p. 17). Muslim spirituality, in particular, aims to shape these fundamental tenets of positive citizenship. Even with standard acculturation and socialization, children's spiritual experiences have the potential to constructively impact and supplement subsequent stages of growth and development. Current perspectives of citizenship tend to overlook the worldview and spiritual experience underlying citizens' cognitive development and identity formation.

The meaning of spirituality, however, remains notoriously difficult to define. Swinton (2001) sees it as a personal and social process that refers to the ideas, concepts, attitudes, and behaviors that derive from a person's or community's interpretation of their experiences of the spirit (Swinton 2001, p. 20). Elkins defines it as "a way of being and experiencing that comes through awareness of a transcendental dimension and that is characterized by specific identifiable values regarding the self, others, nature, life and whatever one considers to be ultimate" (Elkins et al. 1988, p. 10). Others see it as "a way of living, an attitude, a motivation, recurrent integration, and sustained conviction. It is a style, process, and method by which one lives considering the goal. It is an awakening that starts with looking within ourselves for self-discovery and continues until one realizes that we are an integral part of the natural world" (Wane 2011, p. 76), as well as "the determination that the mind produces, known as the power of the will, to refine our human behaviors through our positive thoughts, words, and actions" (Wane 2011, p. 78). However, these views and others are less attentive to the divine (God), tending to marginalize belief or dismiss it altogether, and, to varying degrees, focusing instead on tangible human power, consciousness, personal experience, and beauty manifested in the natural environment as a fundamental axis of spirituality.

\section{Muslim Spirituality}

In this section, we discuss some of the basic foundations, premises, and values underlying the notion of Islamic spirituality as a primer on Islamic spiritual parenting. Spiritual parenting here is understood as an exercise of spirituality in the context of parent-children relationships nearing stewardship that focuses on the transmission and internalization of spiritual discipline, tradition, and values. Spirituality in Islam has a special meaning, form, and character. The Qur'an makes particular reference to human nature using two words interchangeably: ruh (soul, breath, spirit) and nafs (self). According to the Qur'an, the domain of ruh is inaccessible and of which people only have limited knowledge (Qur'an 17:85). According to the tradition of Muslim spirituality, the neglect of the soul eventually results in the corruption and decline of the inner being (Qur'ān, 91:9-10). Spirituality here may be described as the function that regulates the relationship of the human with the Creator himself, one's fellow humans, and surroundings, which also organizes one's mark on future generations. According to Nasr, the term ruhaniyyah is the prevalent translation for spirituality, deriving from al-ruh, meaning 'spiritus'. Nasr defined spirituality as an inner spiritual dimension of traditional religions dealing with the noumenal and formless that can be experienced directly, extending beyond mental categories, but which are not anti-intellectual (Nasr 2006, p. 209). Humans' connection with God affects their worldview, life purpose, relationships with others, and the environment.

According to the Islamic tradition, humans are born free of sin, originally predisposed with an innate belief in the divine, and the inherent need for divine guidance. While human nature includes both good and evil, Islamic traditions teach that humans are also favorably inclined to goodness and virtue, which makes goodness and righteousness inherently 
natural, whereas evil is subject to conscious acquisition or unconscious acculturation. Humans are created in the best stature, which signifies knowing, accepting, and abiding by the provisions of truth (Qur'an 95:4). Muslims believe that God created humans out of clay, and honored them with reason, senses, and intuition. God taught humans the names of things and set them on Earth as viceregents and stewards (Qur'an 2:3031). God also endowed humans with fitrah (innate human nature), in humans' natural predisposition echoed in contemporary notions of tabula rasa. This qualitative approach denotes a characterization of the soul with qualities, either by conscious instilled creation or by habit, leaning more towards creation and inculcation. The notion of fitrah plays a seminal role in education, taking into account children's intrinsic predispositions, while also associated with other interrelated concepts such as free will, servitude to the divine, adaptability, balance, and preparedness for change. Human nature includes fundamental constituents of children's rational, spiritual, emotional, cognitive, and behavioral domains.

In Islam, believers are commanded to bow down to none but God, glorify none but Him, and serve none other than Him. The Qur'an also stresses vital concepts such as the unity of God (tawhid), His overseeing of the creation, His creation of humans for worship, and the accountability of humans before Him on the Day of Resurrection. Tawhid implies that only God is worthy of love, worship, and devotion. Another Qur'anic concept pertains to the need for soul cultivation (tazkiyah), jihad against the self, and the need for thankfulness, mindfulness, self-contentment, and piety.

Islamic spirituality represents a conscious communication with the divine, involving complex sets of interactions and reflective exercises of beliefs, rituals, motivations, values, and decisions. In this regard, spirituality prompts and guides the individual on a quest for truth, commitment, and engagement, eliciting an appreciation for and experience of divine signs in life and all creation. It also helps to regulate the human relationship with the unseen, sacred, transcendental, or divine, providing a configuration that situates humanity in the Cosmos while nonetheless resonating with their genuine needs and aspirations. Spirituality further denotes a state of mind and its connection with God, His signs, and all animate and inanimate creatures, resulting in a distinct awareness of interconnectivity situated within a configuration of regulated normative interactions. However, realizing this requires constant nourishing and training of the soul. The fourteenth-century Muslim scholar, Ibn Qayyim al-Jawziya, in his work Ighathat al-lahfan ('Aid for the Sorrowful'), aptly summarized the concept of Islamic spirituality, describing the root of Islam as "love for God, intimacy with Him, and yearning to encounter Him" (Chittick 2010).

Muslim spirituality embraces the human experience and is constructed through devotion to the divine through beliefs, worship, socialization, and knowledge of the world. Given its content of belief, rituals, behavior, presence in life, and knowledge of the world, Islamic spirituality is not aimed towards self-centered exercises favoring escape from the rules of instruction and objective assessment. AbduSalam Yasin noted that all paths of education are governed under the branch of belief and excellence in worship (ihsan) up until the heart gains purity and rightful devotion to God, whereby the individual becomes the master in control, motivated neither by lust or desire, nor the rush to oppression (Yasin 1998). Spirituality capitalizes on the purification and observation of the acts of the heart and the objective assessment of inner states of the self, nourishing elevated states of being, and cultivating the disciplines of humility, virtue, and good mannerisms.

Islamic spirituality pertains to individuals' experiences built on defined foundations and boundaries, cohesively linked together through clear frameworks that allow for more objective explanations, expressions, and sharing on a social level. Al-Ghazali noted that the formation of innately spiritual states is a necessary prerequisite for the flow of generated knowledge (Al-Ghazali 1995, p. 41). Spirituality also invokes reflection (tafakkur) about the creation and signs of God. Hence, those who ponder about the wonders of creation as manifestations of God's will are guided, while those who reduce the existence of wonderful creation into reductionistic or material mechanical relations of cause and effect will deviate from the divine path (Al-Ghazali 1995, p. 41). 
Muslim spirituality involves various evolving stages and stations of cultivating awareness of the divine, proceeding with the development of piety, virtue, and vigilance from doubtful acts or objects, and abstinence from extravagance-all while enhancing resilience against self-centeredness, selfishness, greed, and all corrupting human influences and impressions on their environment. It first aims to master the self through re-wiring of one's consciousness in the face of temptations; checking attachments to material desires, objects, or images; re-defining the understanding of and approach to happiness and the worth of things; and re-configuring the hierarchy of needs, priorities, and scale of satisfaction. In the field of Islamic spirituality, this manifests through tazkiyah (purification of the soul) among other related key concepts, such as mindfulness (muraqabah), contemplation (mushahadah), retrospection (muhasabah), doing meritorious deeds (tahalli), and elimination of bad qualities (takhalli). The focus of spirituality is holistic, and thus, embraces one's entire personality and open space of contribution to life instead of confining them to specific rituals or restricting individuality. It seeks to cultivate good human habits, exercise the intellect, and embrace all sincere and genuine acts of virtue and common good reflective of the divine will, human reason, and innate human nature.

Therefore, the Islamic conceptualization of spirituality is not approached as an escape, disguise, or diversion, and does not seek to undermine human curiosity towards the universe, or cause disinterest in life or change. Spirituality, instead, assumes an active and powerful role in the making of society, with its credibility externally validated according to truth, rational thought, and positive impact. In this vein, spirituality should not be pursued for exclusion, manipulation, or harm, but rather amid healthy interaction with the community and life.

\section{Theoretical Framework of Parenting}

With different sets of beliefs and performative actions, different cultures and groups develop distinct parenting styles and behaviors. Each society trains and socializes children to ensure they are brought up according to the parenting beliefs inherited from prior generations. Though cultures do change, the process occurs rather slowly, and the crossgenerational transmission of parenting values is absolute (Bornstein 2012). Parental support is based on affectionate constructs such as acceptance, nurturing, and solidarity, making it the most effective dimension of parenting. It involves a parent's action to allow their children to feel accepted by encouraging them. Research has linked increased parental support with heightened functioning among adolescents, leading to fewer problematic behaviors (Barnes et al. 2000; Cummings et al. 2000). Research has further highlighted that harsh treatment and psychological control are linked to developmental issues among children, and may lead to behavioral problems (Pinquart 2017).

Parental control has been further categorized into two main dimensions: behavioral and psychological control. In parental behavior control, parents recurrently use disciplinary strategies by enforcing rules and demands, strict child supervision, and positive and negative reinforcements to control and regulate the actions of their children. While it has been proven that positive child development requires an appropriate amount of behavioral control, poor monitoring and excessive involvement may increase punishments and lead to adverse developments in the child often associated with deviant behaviors and psychological illness (Barber and Harmon 2002; Galambos et al. 2003). In addition, the intrusive control by parents attempting to manipulate a child's emotions and thoughts is a form of parental psychological control. Such manipulative control has been linked to negative child development, leading to antisocial behavior and regressive relation (Barber et al. 2005; Kuppens et al. 2013).

Other scholars have adopted a different approach in the study of parental practices. By combining parental practices in their study of influences on child development, they were able to identify and study patterns of parenting practices and categorize them into parenting styles (Maccoby and Martin 1983). Parenting styles are the amalgamation of attitudes communicated to children to form a dynamic environment for the parents to 
express their behaviors (Darling and Steinberg 1993). In Baumrind's $(1966,1967,1971)$ study introducing parenting styles, he describes three parenting styles: i.e., authoritarian, permissive, and authoritative. Authoritarian parents have a definitive standard set they follow to control, mold, and assess their children's behavior, whereas permissive parents allow their children to have autonomy and tend to be warmer. Between these two extremes lies the authoritative parenting style. Parents' child-rearing attitudes influence parental practices and the environment that parents intend to create for their children. Parental attitudes inform parents' authoritarian and progressive views on child-rearing. Parents with progressive views follow a child-centered approach to help children think independently and voice their opinions. Authoritarian attitudes direct parents to strictly discipline their children to allow them to adhere to authorities and obedience (Bornstein et al. 2011; Steinberg et al. 1991).

Many contemporary theoretical frameworks have been developed to help us understand the relationship between parenting and child development, and how parenting and child development are influenced by several external and internal components, including expectations of social roles. The behavior of both children and parents differs within different contexts, as parents respond differently within different contexts and times (Deci and Ryan 2000). Among these theories are: social learning theory, where children improve their emotional management through experiences, effectively transmitted through direct or indirect parenting (DeGarmo et al. 2004; Patterson et al. 1989); the attachment theoretical model, suggesting that children's emotional health and relationships are positively affected by the responsiveness of parents to fulfilling the needs of their children (Cicchetti et al. 2006; Sroufe et al. 1999); the motivational model, based on three dimensions of parenting style, i.e., structure vs. chaos, autonomy vs. coercion, and warmth vs. rejection, where children are motivated by the basic psychological needs of belonging, competence, and authenticity (Connell and Wellborn 1991; Deci and Ryan 1985; Skinner and Wellborn 1994; Kochanska 1997); and identity theory, referring to the meaningful behaviors of individuals and the existence of bi-directional processes of identity where one tends to influence the maintenance, development and enactment of other identities (Cast 2004). This includes Jean Piaget's cognitive development theory, focusing on the role of the family in the construction of childhood experiences (Christie et al. 2007); the sociocultural theory proposed by Lev Vygotsky, who explained the child's individual relationship with their physical and social environment and their process of knowledge internalization through peer influence (Rieber and Robinson 2004); and finally, Urie Bronfenbrenner's ecological system theory, where children's development is contingent upon internal factors as well as the family and environment, including social, biological, political, and economic conditions situated within concentric structures of overlapping micro, meso, and macro systems (Christie et al. 2007).

\section{Muslim Spiritual Parenting}

The Muslim literature on children's spirituality is interspersed throughout multiple Islamic disciplines. Muslim scholars, like Ibn al-Qayyim al-Jawziyah (1292 AD), Al-Ghazali (1111 d), Abu Zayd al-Qayrawani (996 AD), Al-Ajiri (971 AD), Khawarizmi (850 AD), AlQayrawani (996 AD), Abul Hasan bin khalaf al-Qabisi (1012 AD), and Abu 'Amr Ahmad bin Afifi (1029 AD), among many others, are most prominent in their writings on childhood and spirituality. Currently, Alwan's work Tarbiyat al-awlad fil-Islam ('Education of children in Islam'), first published in 1985, is still considered one of the most renowned sources on children's religious and spiritual education (Alwan 1996). In English literature, very little has been written on Muslim spiritual parenting. One noteworthy work is Beshir (1998) Parenting in the West: An Islamic Perspective. Khurshed Mitchell (2001) addresses aspects of Islamic mothering, but deals more specifically with the context of cultural safety of Muslim mother immigrants. Inayet Sahin writes on the experience of turning to a spiritual path and healing the emptiness. Her study explores Islamic spirituality according to the Sufi perspective, mothers as spiritual teachers, and the spiritual growth of Muslim children (Sahin 2003). Scourfield et al. (2013) also writes on Muslim children's upbringing, with 
close attention paid to the social background of Muslim families and the challenges of parenting in a small ethnic group in Britain. Sandra Anto-Awuakye (2009) explores the parenting styles of South Asian families of different cultural backgrounds, parental values, and attitudes, especially the emotional connectedness in extended families. Hanny Hartono (2012) studies Muslim migrants from diverse backgrounds in New Zealand striving to lead pious lives in a multiethnic society. His work shows how Muslim mothers strive to improve their understanding of Islam and spirituality to improve their roles as mothers and raise good Muslims in an increasingly global Muslim community.

Muslim spiritual parenting is embedded in several fundamental concepts, such as the unity of God (tawhid), innate human nature (fitrah), purification of the self (tazkiyah), reform (islah), stewardship (khilafah), servitude to God ('ubudiyah), success (falah), and good life (hayat tayyibah), among others. The unity of God is regarded as the most fundamental principle, for it provides the simplest possible perception and expression about the Creator, the created, and the relationship of God with His servants, which helps satisfy children's curiosity and imagination about existence and the universe. Parents draw on the concept of tawhid to cater to their children's questions about the concept of the Creator and the secrets of existence and the universe. In addition, Islam encourages parents to listen to and entertain their children's questions and answers referring to the means of dialogue, wisdom (hikma), and delightful admonition (maw'ida al-hasana) in addressing relatives and other people as well. Ibn Miskawayh (d. 1030 AD) considers this portion of parenting knowledge a powerful motivator for raising moral and spiritual children.

Spiritual parenting helps children learn about God, His love, names, and attributes, and trains them as servants of God within all scopes of social interaction, nurturing a deeper interest in their inner moral understanding. In this manner, children are expected to grow the capacity to discover the truth by themselves, explore and experience the meanings of beauty, both intrinsic and extrinsic, and understand their individualized strengths and weaknesses. It also helps them cultivate spiritual meanings, such as sincerity, modesty, piety, righteousness, humility, self-contentment, vigilance from doubtful acts or objects, abstinence of extravagance, and caution from their self-centeredness, selfishness, and greed.

Spiritual parenting starts with parents' spirituality, spiritual interests, tastes, experiences, and environment, as well as their perspectives and commitment to their children's holistic development. This calls for opening wide the windows of interactive learning and connecting with both the spiritual and non-spiritual aspects of life, while simultaneously guarding children from all forms of injustice and intolerance. Moreover, spiritual parenting should be regarded as neither sacralizing nor sanctifying, nor even as an exalting exercise. Instead, it includes a vision and commitment to learning and internalizing knowledge and experiences without restricting children's adaptations, adjustments, and creative imagination. In this, spiritual parenting embraces emotions and reason together, reflecting the consensual partnerships of the guide and guided, the mentor and mentee, and the coach and trainee, without driving those relationships into vaguely imagined holiness, purity, or impeccability.

Spiritual parenting progresses according to certain principles, values, and norms, leading the child gradually to the divine consciousness through a series of practices, selfreflection, meditation, and adaptation. It involves attention to inner motives and constant support of cultivation and purification of the self (tazkiyah), scrutiny and improvement of behavior, participation in and service of the community, and environmental stewardship. Spiritual parenting is primarily concerned with the cultivation of children's character qualities such as love, mercy, forgiveness, forbearance, integrity, justice, resilience, truthfulness, and generosity. As illustrated by Al-Qabisi:

If the rational soul (al-nafs al-'aqilah) realizes its nobility and perceives its rank concerning God, it shall fulfill its task well as deputy (khalifatuhu) in ordering and tending these faculties and shall rise with the help of the power bestowed upon it by God to its place in His esteem and its level of sublimity and honor. 
Spiritual parenting provides children with the necessary learning and experiential conditions favorable for spiritual cultivation, maturity, and development, therefore allowing them to discover themselves and their capabilities, develop their respective identities, nurture their consciousness of the divine presence, and deepen their consciousness of their roles, obligations, and responsibilities towards others and the environment. This requires sensitivity, flexibility, simplicity, transparency, openness, graduality, exposure, adaptation, and above all, perhaps, the realization of both the subjective character of spiritual experience and children's vulnerability to 'fail', 'fall', and 'rebel'.

Spiritual parenting opts for the general status of legal permissibility (ibahah) and concession (rukhsah), except when prohibition strictly applies while sustaining children's moderate attitudes and lifestyles, thus avoiding extreme or radical approaches to discipline, ritual practices, or approaches to life. The literature that promotes the exclusion of one domain at the cost of others further derails the holistic human growth and, hence, is detrimental and counterproductive. Spiritual parenting sets clear boundaries between humans and the divine, God's perfection and human erring, prophets' infallibility from major sins, and the sinning of ordinary people. It respects children's independence, promotes their innocence, freedom, and creativity, encourages their choices and talents, and lets them weave for themselves the spiritual identity they choose away from any maneuvering or manipulation. Following their natural development, children should be gradually exposed to rational concepts, themes, and experiences of spirituality. According to Yasin, gradualism is an essential method in piety discipline, and its education requires patience, moderation, and diversity of approach (Yasin 1998).

\section{Characteristics of Islamic Spiritual Parenting}

In the following paragraphs, we will discuss some of the essential characteristics of Islamic spiritual parenting, with a broader look at the fundamental principles of Islamic belief, law, and morality, as well as a general outlook of Islamic education and spirituality. One should note, however, that the fundamental elements of Muslim spiritual parenting vary not only due to differences in traditional and cultural geographies, but also due to the diverse interpretations of the Qur'an and law, Sufi traditions, orders and discourse, understandings of orthodoxy and heterodoxy, sociocultural and economic conditions, and politics. Muslim spiritual parenting is essentially set within the framework of the Revelation and, hence, operates according to the measures of the Qur'an, traditions, and the life examples of the Prophet Muhammad, his companions, and role models in prior generations. On several occasions, the Qur'an touches on pious parenting (31: 13-19, 20:132, 25:74), introducing fundamental spiritual principles of human development and highlighting key spiritual themes about the responsibility of childcare, education, support, and children's spiritual and moral health. For instance, the use of Qur'anic supplications reinforces Muslims' spiritual consciousness about spiritual parenting (Qur'an 25: 74; 3: 38).

Similarly, the tradition of Prophet Muhammad (Sunnah) elaborates the concept and methodology of spiritual parenting, thus advancing ways, measures, and techniques for children's spiritual character and health. The tradition of Prophet Muhammad lies at the center of children's holistic spiritual excellence. The exposure of Muslim children to his life practice helps them internalize piety and integrity, and encourages them to emulate him as a role model.

Islamic spiritual parenting is knowledge-based and reflects the time and quality of learning invested therein. The parent here is held to the belief that one should dedicate oneself to learning in the name of God, learn and share knowledge, follow in the footsteps of scholars, support learners' communities, acquire the knowledge needed for self-purification, and constantly cultivate one's spirit and moral character. By contrast, parents need to combat ignorance, superstition, and undue submission to masters and authorities. In this way, the parent models by example, training their child in their ways and means of purifying the soul through worship, remembrance of God (dhikr), contemplation (fikr), gratefulness (shukr), mindfulness, repentance (tawbah), vigilance (muraqabah), 
self-auditing (muhasabah), patience (sabr), struggle against oneself (mujahadah), and training of the soul (riyadah). Through this life-long process, children are encouraged to learn basic notions that build character and develop consciousness about the manifested and hidden illnesses of the self, and how to free oneself from burdening vices, pride, arrogance, fear, selfishness, hypocrisy, showing off, etc. The power of contemplation and gratefulness helps generate awareness and consciousness of the divine, His signs, blessings, and bounties, all of which prompt a cycle of positive thinking about the Creator and the created. Remembrance of the divine is a fundamental soft skill to help children develop positive mindsets and practice gratitude to appreciate the blessings of God.

Spiritual parenting is experiential and provides children with real-life spiritual experiences across their ecological spheres of engagement, to grow and strengthen their spiritual aptitudes and competencies. Islam strongly recommends engaging with the community, interacting with it, and serving it. Muslim children are encouraged to attend various prayers such as the five daily congregational prayers, Friday prayers, Ramadan nightly prayers, funeral prayers, and spending time in the mosque ( $\left.i^{\prime} t i k a f\right)$. They are also encouraged to mingle with like-minded friends, known as suhba (good companionship), and avoid and deter unhealthy associations. Al-Ghazali advises searching for friends with good innovative thinking and good conduct, who do not engage in sinful habits and are free from addiction to worldly matters (Al-Ghazali 2019, p. 98). Muslim schools (madrasah) have historically been informed of parents' spiritual expectations and have worked towards improving the school-home spiritual continuum, in addition to engaging with children's respective communities and their spiritual occasions and celebrations, like the month of fasting or Eid celebration.

Spiritual parenting cultivates children's insight, awe, and appreciation of nature, leading them to ponder the origin, secrets, and beauty of creation and the universe. The belief in the creation of humans from clay (Qur'an 23:12) ingrains in them a sense of persuasion of similitude and bonding with the earth (Qur'an 71: 17-20). This implies inter-connectivity with the earth, as showcased in the close attention Islam pays to nature, environmental stewardship, and the idea that humans are the principal driver of change. Indications of viable spiritual consciousness towards the earth and environmental conservation is found in many examples, such as the criteria for soil purity, water use in worship purification, the substitution of water with stone or dust in ablution, regard of water as a source of healing and relief, the Zamzam Well's significance in holy pilgrimage, and recommendations for making invocations during rainfall. In learning how the Qur'an describes it as the source of life (Qur'an 21: 30), the child is not only informed of the importance of physical purity, but also of spiritual purity, and exercises their rational faculties by understanding the necessity of water for biological life.

Several other traditions of Prophet Muhammad elaborate such spiritual linkages, such as the supplications prescribed for weather change, rainfall, windstorms, lightning, thunder, fire, earthquakes, extreme temperatures, calamities and disasters, or eclipses. Those spiritual prayers not only nourish favorable cognitive and emotional grounds for environmental consciousness, but further affect the general bearing of individuals and community vis-à-vis environmental responsibility, stewardship, and a deep regard for nature. Through spiritual reflective practice, children would be motivated to generate meaningful connections with the earth, invest in their natural stewardship, and strengthen their intimacy with the Maker. Those cognitive and emotional effects of spiritual parenting are expected to flourish and, with proper education and guidance, propel resilient ecospiritual capital resistant to greed, hostility, abuse, enmity, or destruction of planetary resources (Qur'an 2:60).

\section{Muslim Spiritual Parenting}

In this section, we will provide a basic outline of Muslim spiritual parenting. Muslim scholars have discussed many approaches and strategies for children's spiritual education and training, defining its primary purpose as the holistic development of the child, its innate 
human nature (fitrah), intellectual, emotional, and physical well-being, as well as their social welfare. However, considering its holistic focus encapsulates a complex moral order within the child's ecological system, there is no rigid and standardized formula for Muslim spiritual parenting. Instead, multiple approaches, techniques, and strategies are found in Revelation, the tradition of Prophet Muhammad, and Muslim experience, which are adaptable to the various contexts of virtues, character, and identity development. Spiritual parenting is affected by certain factors including environment, inspiration, direction, means of acquisition, methods of instruction, disciplinary practice, and purification. Spiritual strategies and techniques involve early introductions of children to the six articles of faith, God's names and attributes, the pursuit of religious knowledge, manners of worship, ethics and a morally informed social etiquette, cultivation of the inner reflexive self, exposure to spiritual role models, good company, and living piously from within and alongside one's community.

Islamic spiritual parenting involves gradually developed conceptions, ethics, measures, and steps taken throughout the parenting journey. From the outset, the Qur'an endorses breastfeeding as a fundamental right for every newborn and infant with strong recommendations for completing a breastfeeding cycle of two years (Qur'an 2: 233), which is emphasized in the case of infants in dire need for milk's nutrition (Bensaid 2021). Furthermore, Islam grants high spiritual merit to infant breastfeeding, encouraging the breastfeeding of children for two years until they attain full health and strength. Arfat notes that Islam has commanded the breastfeeding of children up until they attain full power and strength (Arfat 2013, p. 301).

Upon birth, Muslim parents are encouraged to make the ritual call for prayer in the newborn's ears. This is done with the belief that the call would precede that of Satan, touch the newborn's heart, and sustain an effect (Ibn al-Qayyim 2010, pp. 37-38). Some describe this as a possible analogy, in that both the coming into this world and leaving it are defined by pronunciations of the Islamic testimony of faith. Prophet Muhammad is reported to have supplicated on newly birthed children. Prophet Muhammad recommended the recitation of the following prayers for protection from Satan's influence on children: "With the Name of Allah. O Allah, keep the Devil away from us, and keep the Devil away from that which You provide for us" (Al-Bukhari 2002, p. 49).

Islam also recommends giving pleasant names to newborn children and to avoid naming them forbidden or degrading names. It is reported that Prophet Muhammad changed names with negative meanings, or which affected the self-esteem of children, saying: "On the Day of Resurrection, you will be called by your names and your fathers" names, so make your names good" (Albani 2000, p. 1227). This reflects a belief in the causal relationship between names and the named, particularly in that the meanings of names may influence the child's psyche in the form of a self-fulfilling prophecy. Pleasant names carry over pleasant meanings and act as potential catalysts for embodying values and further positive characteristics. A name is one's title and a reflection of the person they will be referred to throughout their lifetime and on the Day of Judgment.

In early infancy, parents are recommended to practice tahnik (rubbing inside the newborn's mouth with a softened date) while offering Duas (supplications) for the child. The Prophet reportedly practiced this with newborns brought to him and for whom he would supplicate for blessings for them and rub a chewed date upon their palate (Abu Dawud 1988). Muslim parents are also encouraged to offer sacrifices ('aqiqah) for their children's birth. Offering a sacrifice in celebration of birth implies several spiritual merits, such as the spiritual welcome of newborns, thanksgiving to the divine, bonding of families, strengthening of community, reinforced senses of collective spirituality, and serving the needy. According to Ibn al-Qayyim, sacrifice draws the child nearer to the divine and is viewed as mirroring the story of God's pardon of Prophet Abraham in reward for his submission to God and willingness to sacrifice his son Ismail for his sake (Ibn al-Qayyim 2010). Muslim jurists recommend offering the sacrifice within the first week, circumcising 
(only) male newborns, and shaving the baby's hair and giving its equal weight in gold as alms.

Parents should give attention to their children's learning, recitation, and memorization of the words of the Qur'an. To begin nurturing their children's spirituality in a community setting, Muslim parents traditionally and historically send them to katatib (Qur'an schools). The importance of Qur'an memorization is not limited to the ability to recall its content with high accuracy, but also its marked impact on the child's personality. As Helen Boyle notes, in memorizing the Qur'an (or parts thereof), students embody or possess the words of God within their beings, where they can physically reproduce it, share it, and refer to it, ideally throughout their lifetimes (Boyle 2006). Qur'anic memorization is therefore not limited to the mere memorization of words, but also encompasses learning about ethics and a spiritual attachment with the words of God. The memorization intends to contribute to children's spiritual and moral development, enriching their ethical consciousness and manners, social, teamwork, and learning skills, and community responsibility (Bensaid and Machouche 2016). Abdul Rahman Ibn Khaldun noted that Qur'anic instruction not only imbues children's hearts with sound belief, but also cultivates in them fertile grounds for future learning habits while serving as a critical platform for skill development (Ibn Khaldun 1967, pp. 421-22). According to traditional circles of Qur'an memorization, children should leave their wooden tablets in clean places, and if they want to erase written verses after memorization, they should then clean their tablets with clean water and in clean places, to avoid mixing the ink used for writing the words of God with unclean materials. The repeated time spent in memorization also contributes to children's spirituality, as it provides ideal moments for self-reflection, thinking, meditation, tranquility, and focusing on one's relationship with God.

Qabisi considered children's early learning of the Qur'an as a religious educational responsibility incumbent on parents. For him, the discipline of the child follows that of the father (Al-Qabisi 1986, p. 93), and in the case where the father fails to teach his child the Qur'an because of negligence, he (the father) would be regarded as ignorant and shall accordingly be reprimanded. If the father has the means necessary for religious education, he must accordingly send the child to school and pay the instructor his dues (Al-Qabisi 1986, p. 94). The priority of learning the Qur'an, however, is not strictly subject to the father's financial capacity, but can equally be extended to other parties, such as the child's guardian, mother, governor, volunteering instructor, or other generous individuals. Qabisi's view corroborates the position of Islamic law, which places the responsibility of children's Islamic religious learning respectively on their parents, community, and government. According to Qabisi, when the child has no guardian whatsoever, the governor or community leader is then required to assume responsibility. Should the child have no-one to oversee them, the Muslim community should take on the responsibility of their education and spend on the child out of their wealth. If, however, the child comes from a poor economic background with no source of funding, then the Muslim community should either cover the child's expenses or, alternatively, the Qur'an instructor should exempt the child from payment of the tuition fee (Al-Qabisi 1986, pp. 89-90).

In addition to memorization, parents need to provide their children with answers for some of their basic questions, such as "who is Allah?", "where is He?", "what is death?", "what is paradise?", "who is Satan?" and so forth. This introduces the child to the basic Muslim creed ('aqidah), which forms a foundation for the children's spiritual upbringing. This can be held through personal conversations with children. The Qur'an refers to children questioning and conversing, as shown in the Prophet Abraham's inquisitiveness, thinking, and questioning about the religious practices of his community (Qur'an 21, 60). The study circles of primary textbooks are also instrumental. The case of al-murshi al mu'in 'ala al-daruri min al-din of the Maliki jurist, Abu Muhammad 'Abdul Wahid Ibn Ashir (d. 1631), is an excellent example, where Ibn Ashir's informative method drew upon Ash'arite theology, the Maliki law school, and the spiritual path of Abul-Qasim al-Junayd (d. 910 AD). 
Given the critical role of worship rituals in the process of spiritual parenting, parents ought to ensure conducive environments for their children's worship, encourage their observance of spiritual practices and routines, and support their spiritual practice of regular prayers, remembrance of the divine, Qur'an recitation, and reflection (tafakkur) upon the Creator and creation. Regarding spiritual practice, performing the five daily prayers plays a major role in nurturing children's spirituality. Prophet Muhammad commanded Muslims to encourage their children to perform prayers as early as the age of seven. He said: "Command your children to perform Salat (prayer) when they are seven years old and beat them for (not offering) it when they are ten and do not let (boys and girls) sleep together" (Al-Nawawi 2007, p. 116). The regular daily prayers in Islam are seen as a microcosm of Islamic spiritual practice in all its acts and sequences in and of themselves, each carrying a specific role to establish intimate communication and relationships with Allah through supplications.

Children are taught at early ages to recite certain daily supplications for nearly every occasion, such as carrying out ablution, attending prayer at the mosque, commencing and ending of meals, entering and exiting restrooms, sleeping and waking, leaving home, working, looking in the mirror, and receiving new clothing. Similarly, children are taught special invocations for prayers and upon finishing prayers, upon hearing the call for prayer (adhan), sighting the crescent moon, seeking forgiveness and mercy of the divine, expressing gratefulness to God, calling on God for strength when undergoing trials and tribulations, praying for sustenance, and asking for protection from ignorance, oppressors, Satan, and wrongdoers. Other supplications are offered for repentance, righteous company, rainfall and storms, upon hearing thunder, parents' forgiveness, greetings, praying for a blissful family, ending of gatherings, asking forgiveness for oneself and all those entering one's home, responses to sneezing, answering words of praise or insult, praying for confidence and eloquence, seeking happiness and increased knowledge, upon receiving good or bad news, in sickness and pain, in times of distress, anger, seeking guidance on matters, when feeling frightened, weakness, for patience, lending money, taking rides, for someone offering a meal, for thanking, travel, in settling debts, in offering condolences, when invited to a feast, in entering the market, when visiting the sick, and when one is in need.

In addition to what has been said about daily prayer, the practice also provides effective early acquisition of healthy hygiene habits, good time management, filial community feelings, and strengthening moral immunity against evil and corruption, all done in tandem with spiritual practices and invocations. Parents are required to guide their children and provide them with the opportunity to learn the individually required religious knowledge (fard 'ayn) of the prayers, and to accompany them to attend the congregation prayers at the mosque. This worship ritual base gives the child more opportunity for socialization and participation in the community's environment and life, which gives them self-confidence, objectives, and life meaning, and qualifies them to acquire social soft skills, such as cooperation and teamwork, effective communication, empathy, altruism, and respect.

As in the example of the Prophet being appointed as a perfect example for humankind (Qur'an 33:21), so too is the parent appointed as the role model (uswa) for their child, not only in delivering theoretical knowledge on spirituality to the child, but also by demonstrating it daily. In several instances, the Qur'an identifies a direct relationship between the spirituality of the parent and their children. Due attention is also needed for lawful (halal) consumption in finances, and the avoidance of illegal incomes that contaminate the family's spiritual health. Muslim scholars are deeply cognizant of this relationship, and consider it key to learning and parenting. For them, the parent's spiritual health carries effectual consequences on the spiritual well-being of their children. This can be observed in the attention and importance given to the spouses' spiritual state and commitments to family spiritual care and health, and the effective and consistent cooperation between spouses in parenting. It also extends to the divine rights granted to children entailing endless dictums and details in the Qur'an and prophetic tradition on 
their feeding, clothing, and protection throughout their development and as they transition into adulthood in full possession of their rational and free will capacities.

Parents, therefore, act as spiritual role models and need to commit themselves to selfreform and purification before extending spiritual guidance to their children. Al-Ghazali stressed observing conformity between "knowing" and "doing" (knowledge and action), drawing on the advice of the early Muslim mystic al-Junayd (d. 910 AD) to one of his disciples to be "neither destitute of good deeds nor devoid of spiritual states, for mere [theoretical] knowledge will not help" (Al-Ghazali 2005, p. 8, Letter to a Disciple). Ibn al-Qayyim (d.1350 AD) noted that parents may cause their children misery, both in this world and in the hereafter, especially when they view their negligent treatment towards them as generosity. He recommends that children need to be guided towards observing the rights, commands, and rules of the divine (Ibn al-Qayyim 2010, p. 351). He urged parents to avoid exposing their children to unlawful influence or wrongdoing, foul language, or taking things from others; instead, they should be taught to give to others (Ibn al-Qayyim 2010, pp. 349-50).

The parent should know that the child is a trust placed in their care that needs full attention. Ibn al-Jawzi listed several measures to be taken in this regard, among them making their child avoid negative company, teaching them what is good, and making them love shyness/modesty and generosity. According to Ibn Al-Jawzi, they should be encouraged to wear white clothes, as recommended by the Prophet Muhammad, tell stories of the righteous, and not be prevented from reading poems inculcating generosity and courage (Ibn al-Jawzi 2011). Furthermore, parents should encourage their children to learn about the inspiring lives and examples of people of piety, wisdom, and devotion, facilitate their understanding of spiritual illnesses, and help them absorb the true meaning of life, besides teaching them lawful and unlawful acts, practicing distance from sinning, and observing a modest dress code, especially avoiding gold and silk (Al-Ghazali 2005, pp. 956-57). Despite the dislike of dressing children in silk given the reported Islamic broad prohibition, the logic is purely educational; children should be taught reprehensibility to be trained in it quickly and avoid it in their later years. Imam Malik (d. 795 AD) is reported to have said: "I disapprove of youths wearing any gold because I heard that the Messenger of Allah forbade wearing gold rings, and I disapprove of it for males old or young" (Ibn Anas 1985). Specifically, parents should educate their children on the proper manners and etiquette of eating food, dressing, sleeping, entering and leaving the house, taking rides, and so forth. They should also inculcate in them praiseworthy characteristics and qualities, such as love of sacrifice, altruism, bravery, nobility, and generosity (Cook and Malkawi 2010, pp. 80-87).

Ibn Miskawayh (d. 932 AD) argued that children's spiritual training seeks to influence their soul, conduct, and appearance. Children should be praised for their good deeds, motivated, and commended to rise above the drive of food, drink, and clothing, and instead be content with small amounts, and trained to admire generous characteristics, warn them of punishment, and make them fear the consequences of their wrongdoings (Ibn al-Jawzi 2011). A man once told Sufyan al-Thawri: "We hit our children if they do not pray." Sufyan told him: "You should rather [encourage them and] give them glad tidings." Moreover, Zubayd al-Yafi used to tell young boys: "Whoever prays will have five walnuts" (Ibn al-Jawzi 2011).

In some cases, the reward will prove futile, especially when the child is resistant or stubborn. Therefore, most Muslim educators discourage using severe or harsh means in discipline, instead encouraging softer ways to redirect the child's behavior. Ibn Khaldun (d. 1403 AD) considered severe punishment in instruction harmful to learners, especially little children, inciting feelings of oppression and leading them to lose energy and interest. Thus, they fall into laziness and resort to lying and insincerity (Ibn Khaldun 1967, pp. 424-25).

Islamic parenting takes into consideration the notion of children's eventual legal majority (bulugh), following which they would attain their independently legal accountability and would be treated as adults. With this in mind, one of the primary objectives of spiritual parenting is paving the way for adulthood and impending autonomy, independence, and 
full legal responsibility. This finds tremendous theological and legal support in Islam, with great emphasis placed on individual moral responsibility and legal accountability. Spiritual parenting in Islam recognizes the critical role of social learning, independent thinking, and experience, and engages the child through their physical surroundings and social ecosystem in a process of continuous learning, interaction, participation, and service of both their community and surroundings. While spiritual parenting superficially may appear to endorse control over the child's emotional and spiritual growth, the learning process involving parents and the community alike is an open and dynamic practice, with styles and strategies in a perpetual state of improvement and change as a result of openness to education, interactive experiences, and community engagement.

Throughout this process, parents are urged to exhibit positive role model behavior and maintain reasonable management and a modicum of conformity to religious statutes in the home, beginning with a commitment to refining and improving their thoughts, attitude, and character. Parents are required to ensure the care and welfare of their children, secure their needs, and ensure their health, moral, and emotional well-being needs are met. Islam commands working and sustaining one's household, and considers work for the same of the family as ibadah fi sabil Allah, with fatality in pursuit of this cause considered martyrdom. Simultaneously, Islam strongly condemns the neglect, abuse, maltreatment, or violation of children's rights. Parents are entreated to forge warm relationships with their children and embrace understanding, compassion ( $\mathrm{rahma} / \mathrm{ra}$ 'fa), kindness (ihsan), gentleness ( $\mathrm{rifq}$ ), forgiveness, and support, while opting for a balanced approach between encouragement (targhib) and warning (tarhib). These meanings and values are firmly established in the Islamic tradition of education and development, and are vividly present in the life history of the Prophet Muhammad. While spiritual parenting carries a distinct worldview, philosophy, and ethical practice, it prioritizes the continuity of healthy interactive learning on the individual level for both child and parent, and, more broadly, as a social mechanism for development. Such a perspective makes the vision of spiritual parenting a strong alternative framework subject to discussion, review, and adaptation, especially regarding the development of intercultural and multireligious theoretical frameworks and practical parenting practices.

\section{Conclusions}

Spiritual education and discipline rest at the heart of moral development and education. Spiritually enriched parenting practices have the potential to guide education to build children's characters, cultivate their inner and outer selves, drive their motives and persuasions towards higher meaning and purpose, shape their disciplinary routines, and further enhance the quality of their contributions to nature and their social surroundings. This broad overview of Muslim spiritual parenting calls for the development of a spiritually-based parenting program that draws on the Islamic literature of spirituality, fundamental Islamic principles and concepts of belief, morality, and law, to inform notions of self-cultivation and development, interpersonal relations, social interactions, and modes of child spiritual practice. However, the design and implementation of this program require a holistic, critical, and open perspective towards Muslim spiritual literature and wisdom.

Classical Islamic literature is replete with rich philosophies, theories, and practices of Islamic spiritual parenting accumulated over centuries and from diverse Muslim geographies. A great deal of literature is found among the fields of Islamic law, Qur'an exegesis, hadith, tasawwuf, ethics, and preaching. While much of the interpretations of the fundamental texts are shared among Muslim scholars, there is significant complexity in cataloging and interpreting shared experiences and performative spiritual parenting practices, especially concerning tasawwuf and cultural practices. A systematic and methodical examination of the legal maxims, diverse ranges of cultural and spiritual traditions, as well as perceptions and practices of said practices within social ecosystems and individuals, is required to fully describe the scopes of spiritual and Islamic parenting, particularly with 
regard to educational psychology, child development theories, and religious and cultural fields of inquiry.

Attention should be given not only to the critical reading of transmitted and experienced spiritual wisdom and its associated pedagogies, methods, and strategies of spiritual instruction and role modeling, but also to the broader structure of spirituality regarding belief, law, and ethics. In addition to taking advantage of the evolving overall global research on parenting and children's education, there is also a need to carefully examine current Muslim spiritual education practices, concepts, and theories, and to understand how spirituality affects Muslim thought and social dynamics. Besides exploring the significance of self-reflexive parental and child spiritual practice on spiritual discourses, it is essential to examine the prospects of Muslim education, identity, and families in the light of their spiritual development and-perhaps most importantly—question how Muslim spirituality is currently coping and adapting to a variety of emerging contexts and challenges of change and development.

Funding: This research received no external funding.

Conflicts of Interest: The authors declare no conflict of interest.

\section{References}

Abu Dawud. 1988. Sahih Sunan Abi Dawud, 1st ed. No. 5106. Edited by Muhamad Nasir al-Din al-Albani. Riyadh: Maktabat al-Tarbiyah al-Arabi li-Duwal al-Khalij.

Albani, M. Nasirul Din. 2000. Dhaif al-Targhib wal-Tarhib, 1st ed. Riyad: Maktabat al-Maarif.

Al-Bukhari, Mohammad ibn Ismail. 2002. Sahih Al-Bukhari, Book of Ablution. Hadith No. 141. Damascus: Dar Ibn Kathir, p. 49.

Al-Ghazali, Abu Hamid. 1995. Al-Tafakkur fi Khalq Allah. Edited by Maher al-Munjid. Beirut: Dar al-Fikr al-Mu'asir.

Al-Ghazali, Abu Hamid. 2005. Ihya' Ulum al-Din. Book of Disciplining the Self. Beirut: Dar Ibn Hazm, p. 955.

Al-Ghazali, Abu Hamid. 2019. Essential Ihya' Ulum al-Din. The Revival of the Religious Science. Translated by Fazlul Karim. Petaling Jaya: Islamic Book Trust.

Al-Nawawi, Yahya. 2007. Riyadh Salihin Min Kalam Sayyid Al-Mursalin. Beirut: Dar Ibn Kathir, p. 116.

Al-Qabisi, Abul Hassan'Ali. 1986. Al-Risalah al-Mufassalah li-Ahwal al-Muta'alimin Wa Ahkam al-Mu'allimmin wa al-Muta'allimin. Edited by Muhammad Khalid. Tunis: al-Sharikah al-Tunisiyyah li Tawzi'.

Alwan, Abdullah Nasih. 1996. Child Education in Islam. Saudi Arabia: Dar Al Salam.

Anto-Awuakye, Sandra. 2009. An Exploration into the Child Rearing Practices of South Asian Communities Living in London's East End. Available online: https://www.researchgate.net/publication/265272736_An_exploration_into_the_child_rearing_ practices_of_South_Asian_communities_living_in_London \T1 \textquoterights_East_End (accessed on 26 November 2021).

Arfat, Shabina. 2013. Islamic perspective of the children rights: An overview. Asian Journal of Social Sciences and Humanities 2: 299-307.

Barber, Brian K., and Elizabeth Lovelady Harmon. 2002. Violating the self: Parental psychological control of children and adolescents. In Intrusive Parenting: How Psychological Control Affects Children and Adolescents. Washington: American Psychological Association, pp. 15-52. [CrossRef]

Barber, Brian K., Stolz Heidi E., Olsen Joseph A., Collins W. Andrew, and Burchinal Margaret. 2005. Parental support, psychological control, and behavioral control: Assessing relevance across time, culture, and method. Monographs of the Society for Research in Child Development 70: 1-147.

Barnes, Grace M., Alan S. Reifman, Michael P. Farrell, and Barbara A. Dintcheff. 2000. The effects of parenting on the development of adolescent alcohol misuse: A Six-Wave latent growth model. Journal of Marriage and Family 62: 175-86. [CrossRef]

Baumrind, Diana. 1966. Effects of authoritative parental control on child behavior. Child Development 37: 887-907. [CrossRef]

Baumrind, Diana. 1967. Child care practices anteceding three patterns of preschool behaviour. Genetic Psychology Monographs 75: 43-88. [PubMed]

Baumrind, Diana. 1971. Current patterns of parental authority. Developmental Psychology 4: 1. [CrossRef]

Bensaid, Benaouda. 2021. Breastfeeding as a Fundamental Islamic Human Right. Journal of Religion and Health 60: 362-73. [CrossRef]

Bensaid, Benaouda, and Salah ben Tahar Machouche. 2016. Memorizing the Words of God: Special Reference to 'Abdul Rahman IBN Khaldun (D. 1406 A.D.). Religious Education 112: 339-50. [CrossRef]

Beshir, Ekrim. 1998. Parenting in the West: An Islamic Perspective. Vermont: Amana Books Inc.

Bornstein, Marc H. 2012. Cultural approaches to parenting. Parenting 12: 212-21. [CrossRef]

Bornstein, Marc H., Diane L. Putnick, and Jennifer E. Lansford. 2011. Parenting attributions and attitudes in cross-cultural perspective. Parenting 11: 214-37. [CrossRef]

Boyle, Helen N. 2006. Memorization and Learning in Islamic Schools. Comparative Education Review 50: 478-95. [CrossRef]

Cast, Alicia D. 2004. Well-being and the transition to parenthood: An identity theory approach. Sociological Perspectives 47: 55-78. [CrossRef] 
Chittick, William. C. 2010. Islam: A Religion of Love. Huffington Post. October 14. Available online: http:/ / www.huffingtonpost.com/ william-c-chittick-phd/islam-as-a-religion-of-lo_b_757352.html (accessed on 16 June 2014).

Christie, James, Billie Enz, Myae Han, Jennifer Pryor, and Maureen Gerard. 2007. Effects of environmental print on young children's print recognition. In Investigating Play in the 21st Century. Lanham: University Press of America, pp. 220-28.

Cicchetti, Dante, Fred A. Rogosch, and Sheree L. Toth. 2006. Fostering secure attachment in infants in maltreating families through preventive interventions. Development and Psychopathology 18: 623-49. [CrossRef] [PubMed]

Connell, James P., and James G. Wellborn. 1991. Competence, autonomy, and relatedness: A motivational analysis of self-system processes. In Self Processes and Development. Edited by Megan R. Gunnar and Alan Sroufe. New Jersey: Lawrence Erlbaum Associates, Inc., pp. 43-77.

Cook, Bradley J., and Fathi H. Malkawi. 2010. Classical Foundations of Islamic Educational Thought: A Compendium of Parallel English-Arabic Texts. Provo: Brigham Young University Press, pp. 80-87.

Cummings, E. Mark, Patrick T. Davies, and Susan B. Campbell. 2000. Developmental Psychopathology and Family Process. New York: The Guilford Press.

Darling, Nancy, and Laurence Steinberg. 1993. Parenting style as context: An integrative model. Psychological Bulletin 113: 487. [CrossRef]

Deci, Edward L., and Richard M. Ryan. 1985. The general causality orientations scale: Self-determination in personality. Journal of Research in Personality 19: 109-34. [CrossRef]

Deci, Edward L., and Richard M. Ryan. 2000. The" what" and" why" of goal pursuits: Human needs and the self-determination of behavior. Psychological Inquiry 11: 227-68. [CrossRef]

DeGarmo, David S., Gerald R. Patterson, and Marion S. Forgatch. 2004. How do outcomes in a specified parent training intervention maintain or wane over time? Prevention Science 5: 73-89. [CrossRef] [PubMed]

Elkins, David N., L. James Hedstrom, Lori L. Hughes, J. Andrew Leaf, and Cheryl Saunders. 1988. Toward a HumanisticPhenomenological Spirituality: Definition, Description and Measurement. Journal of Humanistic Psychology 28: 5-18. [CrossRef]

Galambos, Nancy L., Erin T. Barker, and David M. Almeida. 2003. Parents do matter: Trajectories of change in externalizing and internalizing problems in early adolescence. Child Development 74: 578-94. [CrossRef]

Hartono, Hanny. 2012. The Making of Muslim Spaces in an Auckland Suburb. New Zealand Journal of Asian Studies 14: 38-53.

Ibn al-Jawzi, al-Hafiz Abul Faraj. 2011. Disciplining the Soul. Translated by Ayman Ibn Khalid. Birmingham: Dar as-Sunnah Publishers.

Ibn al-Qayyim, Al Jawziyya. 2010. Tuhfat al-Mawdud bi Ahkam al-Mawlud, 1st ed. Edited by Uthman ben Jumu'ah Dumayri. Annotated. Makkah: Dar Alam al-Fawa'id.

Ibn Anas, Malik. 1985. Muwatta'. Book of Dress, 48, Hadith no. 2. 4. Edited by Muhammad Rahimuddin. Lahore: Ashraf.

Ibn Khaldun, Abdul Rahman. 1967. The Muqaddimah. Edited by Nessim J. Dawood. Translated by F. Rosenthal. Bollingen Series; London: Princeton University Press, pp. 424-25.

Kochanska, Grazyna. 1997. Multiple pathways to conscience for children with different temperaments: From toddlerhood to age 5. Developmental Psychology 33: 228. [CrossRef] [PubMed]

Kuppens, Sofie, Laura Laurent, Mieke Heyvaert, and Patrick Onghena. 2013. Associations between parental psychological control and relational aggression in children and adolescents: A multilevel and sequential meta-analysis. Developmental Psychology 49 : 1697. [CrossRef] [PubMed]

Maccoby, Eleanor, and John Martin. 1983. Socialization in the context of the family: Parent-child interaction. In Handbook of Child Psychology: Socialization, Personality, and Social Development. Edited by Mavis Hetherington and Paul Mussen. New York: Wiley, vols. 4, pp. 1-101.

Mitchell, Khurshid. 2001. Childbirth: A Momentous Occasion Muslim Women's Childbirth Experiences. Master's dissertation, Victoria University of Wellington, Wellington, New Zealand. Unpublished. Available online: http:/ / researcharchive.vuw.ac.nz/xmlui/ bitstream/handle/10063/175/thesis.pdf?sequence=2 (accessed on 23 November 2021).

Nasr, Hossain. 2006. Spirituality and Science Convergence or divergence? In The Essential Sophia. Indiana: World Wisdom Inc., pp. 207-18.

Patterson, Gerald R., Barbara D. DeBaryshe, and Elizabeth Ramsey. 1989. A developmental perspective on antisocial behavior. American Psychologist 44: 329-35. [CrossRef]

Pike, Graham C. 1997. The Meaning of Global Education: From Proponents' Visions to Practitioners' Perceptions. Ph.D. dissertation, University of York, York, UK. Unpublished.

Pinquart, Martin. 2017. Associations of parenting dimensions and styles with externalizing problems of children and adolescents: An updated meta-analysis. Developmental Psychology 53: 873. [CrossRef]

Rieber, Robert W., and David K. Robinson. 2004. The collective as a factor in the development of the abnormal child. In The Essential Vygotsky. Boston: Springer, pp. 201-19.

Rifkin, Leora V. 2016. Defining a Positive Citizenship; Wellbeing for Emancipation. Master's thesis, University of Pennsylvania, Philadelphia, PA, USA. Unpublished.

Sahin, Inayet. 2003. The Experience of Turning to a Spiritual Path and Healing the Emptiness. Master's thesis, University of Maryland, College Park, MD, USA. Unpublished.

Scourfield, Jonathan, Sophie Gilliat-Ray, Asma Khan, and Sameh Otri. 2013. Muslim Childhood: Religious Nurture in a European Context. Oxford: Oxford University Press. 
Skinner, Ellen A., and James G. Wellborn. 1994. Coping during childhood and adolescence: A motivational perspective. Life-Span Development and Behavior 12: 91-133.

Sroufe, L. Alan, Elizabeth A. Carlson, Alissa K. Levy, and Byron Egeland. 1999. Implications of attachment theory for developmental psychopathology. Development and Psychopathology 11: 1-13. [CrossRef]

Steinberg, Laurence, Nina S. Mounts, Susie D. Lamborn, and Sanford M. Dornbusch. 1991. Authoritative parenting and adolescent adjustment across varied ecological niches. Journal of Research on Adolescence 1: 19-36.

Swinton, John. 2001. Spirituality and Mental Health Care: Rediscovering a 'Forgotten' Dimension. London: Jessica Kingsley Publishers.

Wane, Njoki N. 2011. Spirituality: A Philosophy and a Research Tool. In Spirituality, Education \& Society. Leiden: Brill, Available online: https:/ / brill.com/view/book/edcoll/9789460916038/BP000006.xml (accessed on 15 November 2021).

Yasin, AbduSalam. 1998. Al-Ihsan, 1st ed. Al-Dar al-Beida: Matbu'at al-Ufuq, p. 318. 